\title{
Radioisotopic perfusional assessment of blood circulation changes in skin under progressive expansion - experimental model with rabbits ${ }^{1}$
}

Edith Kawano Horibe ${ }^{2}$

Kose Horibe $^{3}$

Horibe EK, Horibe K. Radioisotopic perfusional assessment of blood circulation changes in skin under progressive expansion - experimental model with rabbits. Acta Cir Bras [serial online] 2004 Vol 19 Special Edition. Available on URL: http://www.scielo.br/acb.

ABSTRACT - The purpose of this experimental model with rabbits is investigating the variation of blood flow in the expanded skin versus expansion time. New Zealand breed rabbits are used. Two groups are studied: F-1 receiving expanders on the right tight and F-2 receiving expanders bilateraly. Progressively, five expansions are performed. The first radioiosotopic perfusional evaluation is performed just after the surgery and the following evaluation are performed at the second, sixth, thirteenth, twentieth and twentyseventh post-surgical days. As radiotracer, technetium $99 \mathrm{~m}$ are used in the chemical form of sodium pertechnetate. Scintillographic images are obtained by CGR scintillation camera. The quantitative analysis is done by calculation of the reperfusion rate.

KEY WORDS - Perfusion. Radioisotopes. Skin. Tissue expansion. Model Animal. Rabbit.

\section{Introduction}

Tissues expander is a surgical procedure aiming to expand the skin in deformities repair, which was introduced in 1978, by Radovan ${ }^{1}$.

It is an empty silicone purse, with variable size and shape, either connected to a valve by a tube or directly connected, through which a certain volume of fluid is periodically injected.

This process aims to imitate the distension of the soft parts of tissues, which we can see in certain conditions, as periods of fattening, pregnancy, breast feeding, hematoma, and in growing tumors.

\section{Proposition}

The purpose of this experimental model with rabbits is investigating the variation of blood flow in the expanded skin versus expansion time.

\section{Method description}

White male seven-month old weighting from 2.8 to $3.2 \mathrm{~kg}$ New Zealand breed rabbits were used. During all the time animals were maintained in individual cages, fed with the same kind of food, within a scientifically suitable bioterium.

\footnotetext{
${ }^{1}$ Experimental model developed as a PhD thesis presented to Surgical Department of Medicine Faculty of São Paulo University - USP 
Animals were randomly divided into two groups: group F-1 receiving expanders on the right tight and using their symmetric area of the left thigh as control; group F-2 receiving expanders bilaterally, expanding only towards the right side.

Progressively, five expansions were performed and in each one $10 \mathrm{ml}$ of physiologic solution were injected, starting from the surgical act, when the first expansion was performed, followed by the third, seventh, fourteenth, and twenty-first days, when the maximal expansion was reached $-50 \mathrm{ml}$.

Rabbits of F-1 and F-2 groups were studied during the surgery and afterwards in the second, sixth, thirteenth, twentieth, and twenty-seventh post-operative days.

\section{Surgical technique}

Rabbits were identified by fixing a radiography film $(2.0 \times 3.0 \mathrm{~cm})$ with a monofilament nylon thread 4-0 on the right ear, writing numbers with surgical pen.

Two hours before the surgical act, trichotomy was performed on the study areas, then the animal was immobilized, exposing the side face of $\mathrm{R}$ thigh.

Endovenous anesthesia with $2.5 \%$ sodium thiopenthal (Thionembutal) and $0.0125 \mathrm{mg} / \mathrm{ml}$ of athropin sulfate was carried out, using the marginal ear vein as administration via. After anti-septic procedure with iodine alcohol, and field placement, limits of the expander and valve to be applied on the thigh were marked with shiny green color (FIGURE 1). An empty $50 \mathrm{ml}$, silicone, semispherical, with 6 cm diameter expander was used.

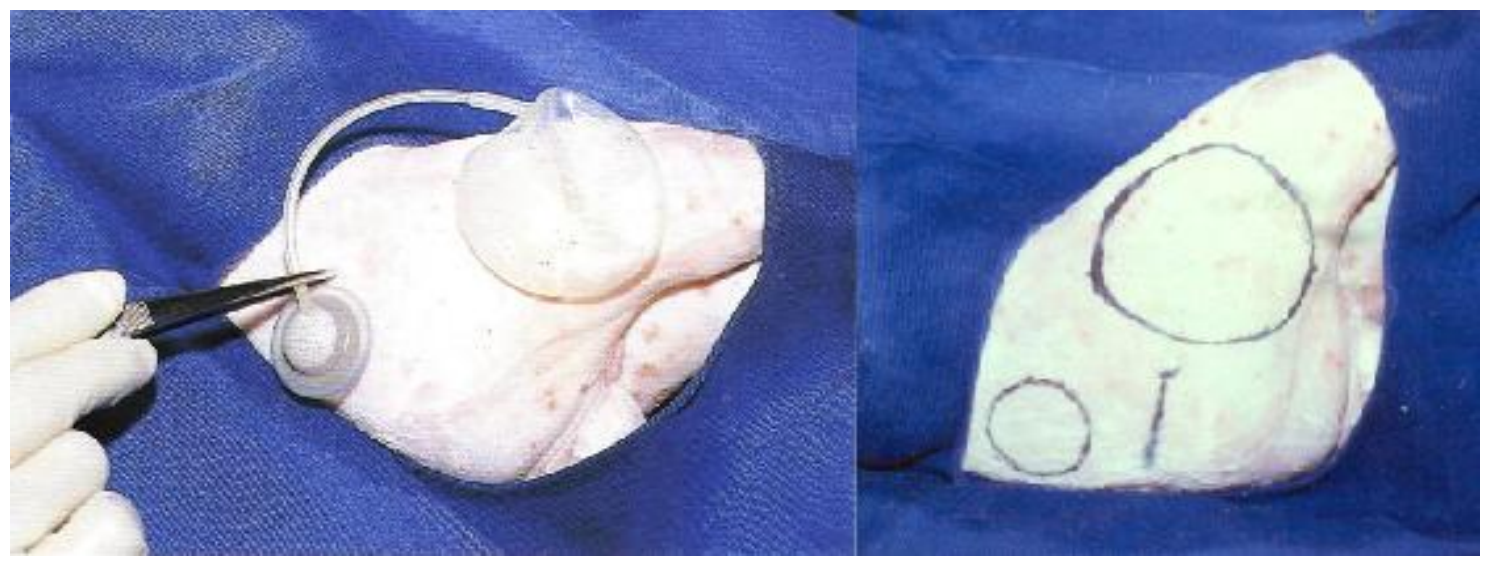

FIGURE 1 - Marking expander and valve limits to be applied on the thigh with shiny green color.

A 3-cm straight line was market between the expander and the valve, cranially positioned, over which the skin incision was performed (FIGURE 2).

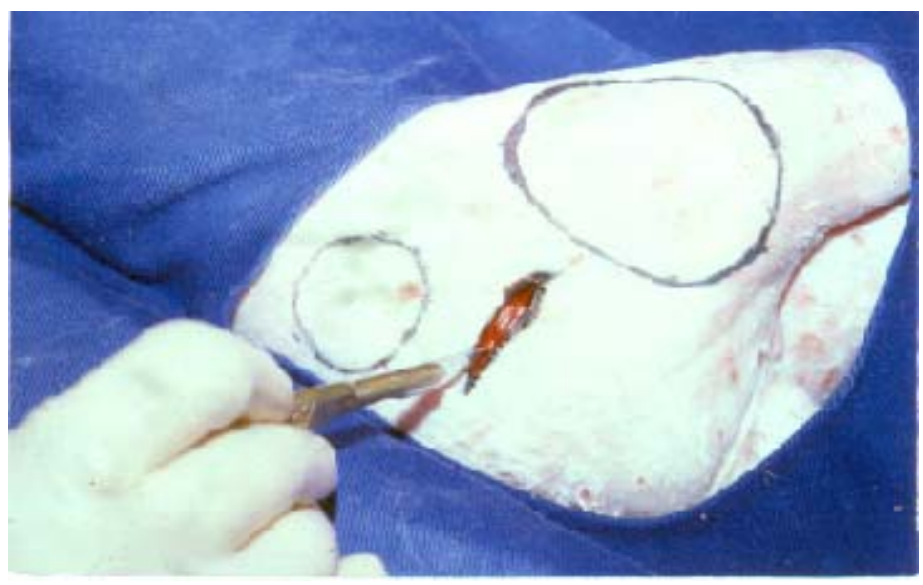

FIGURE 2 - Incision of skin over the mark. 
Air was infiltrated under pressure with syringe, between muscle fascia and skin with fleshy paniculus, where an easy clivage plane of areolar tissue is present. These planes were separated by rhombic dissection, one centimeter surpassing the marked area, so that a wide room was opened to receive the expander. Similarly, the displacement of the suitable area for the valve was proceeded.

Both expander and valve were placed into their respective rooms (FIGURE 3), and this was fixed with a monofilament nylon thread 5-0 (FIGURE 4). $10 \mathrm{ml}$ of physiologic solution are injected through the remote valve (FIGURE 5).

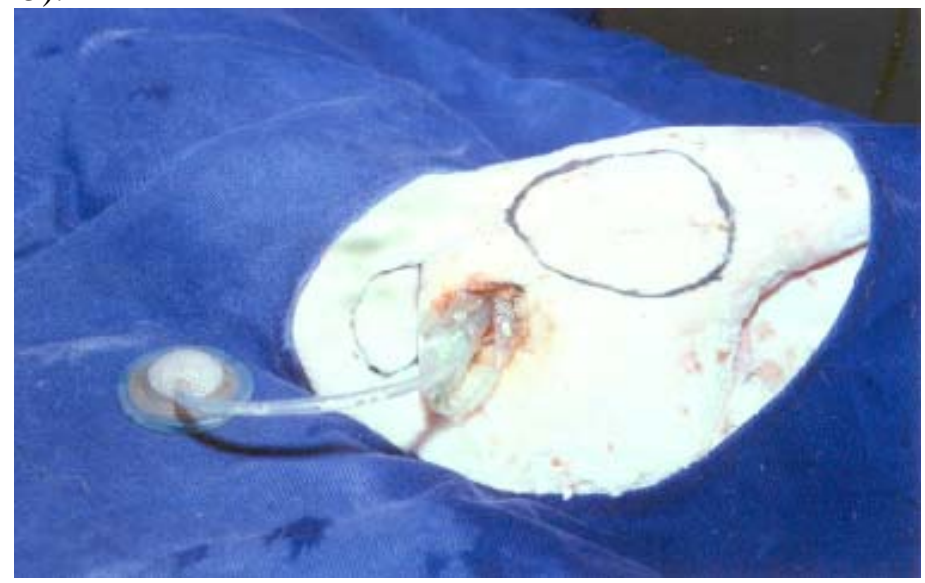

FIGURE 3 - Insertion of expander and valve in their respective rooms.

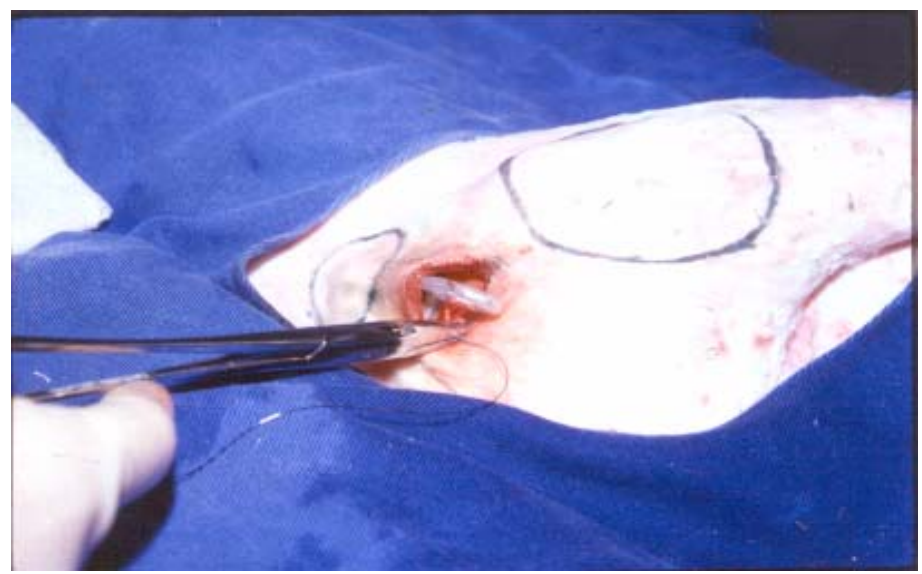

FIGURE 4 - Fixing the expander with monofilament nylon thread 4-0.

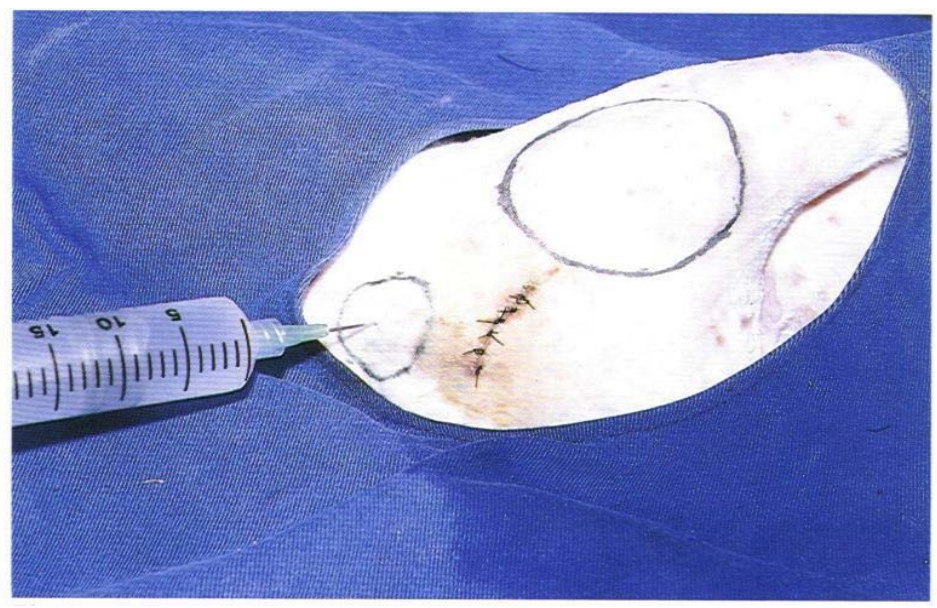

FIGURE 5 - Infiltration of $10 \mathrm{ml}$ of physiologic solution through the remote valve, to inflate the expander. 
applied.

The incision was sutured with the same thread and a gauze and micropore sticking plaster is

Then, progressively five expansions were performed and $10 \mathrm{ml}$ of physiologic solution were injected in each expansion, starting from the surgery, when the first expansion was performed, followed by the third, seventh, fourteenth, and twenty-first days, when the maximal capacity of the expander was reached - $50 \mathrm{ml}$ (FIGURE 6).

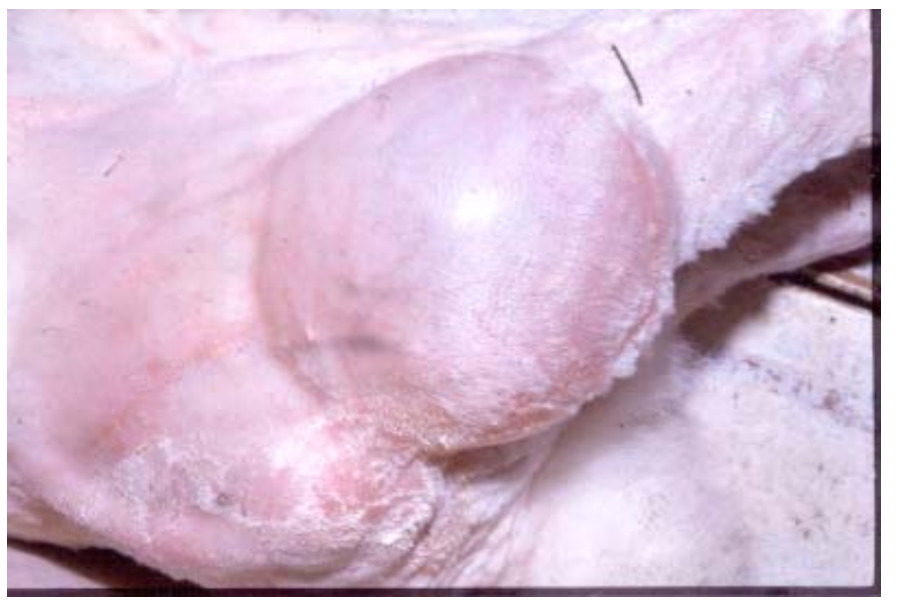

FIGURE 6- Final aspect of the expanded skin with the maximal capacity of the expander $-50 \mathrm{ml}$.

In the F-2 group animals, as expanders were placed on their $\mathrm{R}$ and $\mathrm{L}$ thighs in order to have symmetric marking, a plastic mould was used with three fixed anatomical points (coccyx, side epicondile and medial epicondile) on which the right side mark was projected, and transferred to the opposite side (FIGURE 7).

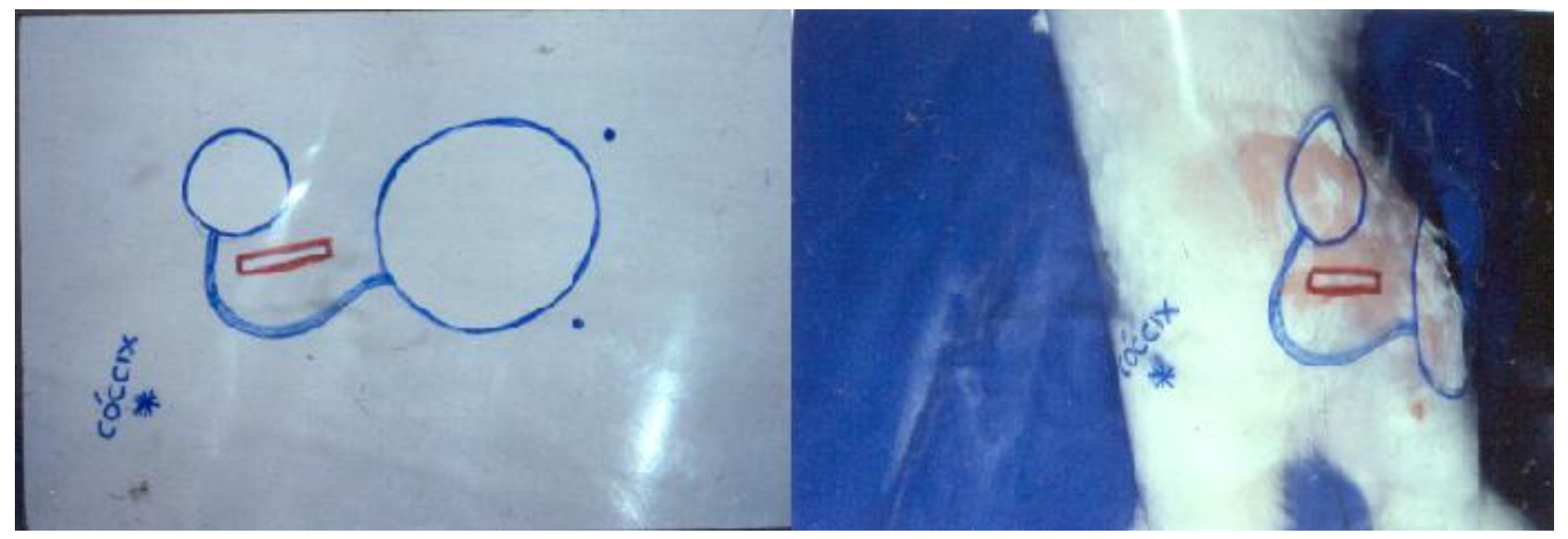

FIGURE 7- Plastic mould on which the right side mark was projected being transferred to the opposite side.

Surgical technique was identical for both sides.

The immediate expansion with $10 \mathrm{ml}$ of physiologic solution only in the $\mathrm{R}$ side was performed, as well as subsequent expansions.

\section{Post-surgical care}

As antibiotic, a $50 \mathrm{mg} /$ day intra-muscle via dose, tetracycline was used as a single dose, starting in the intra-surgical period, and it was maintained up to the 5th post-operative day.

The suture was removed from the skin in the $7^{\text {th }}$ post-surgical day. 


\section{Study of Radioisotopic Perfusional Assessment}

The first radioisotopic perfusional evaluation was performed just after the surgery, thereafter known as time zero, and the following evaluation were performed at the second, sixth, thirteenth, twentieth, and twenty-seventh post-surgical days, i.e., at the eve of the next expansion.

As radiotracer, technetium $99 \mathrm{~m}\left({ }^{99 \mathrm{~m}} \mathrm{Tc}\right)$ was used in the chemical form of sodium pertechnetate, obtained by a mollybdenium-99 $\left({ }^{99} \mathrm{Mo}\right)$ generator, provided by Institute of Research Energetic and Nuclear (IPEN).

Scintillographic images were obtained by a CGR scintillation camera with wide action field and equipped with parallel holes collimator, with low energy and high resolution (HRBE - 7 - 160 - GC) (FIGURE 8).

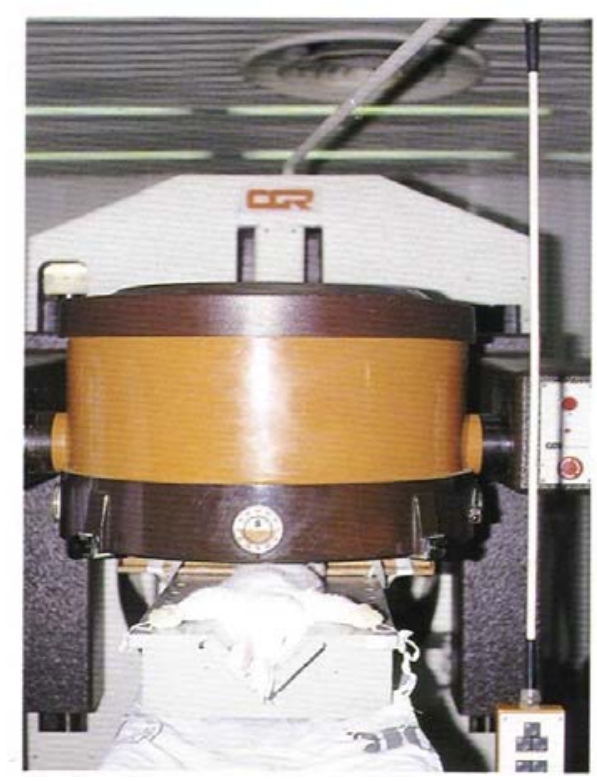

FIGURE 8 - CGR scintillation camera, used for obtaining scintillographic images.

Scintillographic studies processing was performed in a SOPHA S-500 computer system with 128 Kbytes of memory and endowed with a specially developed computer program for this model (FIGURE 9).

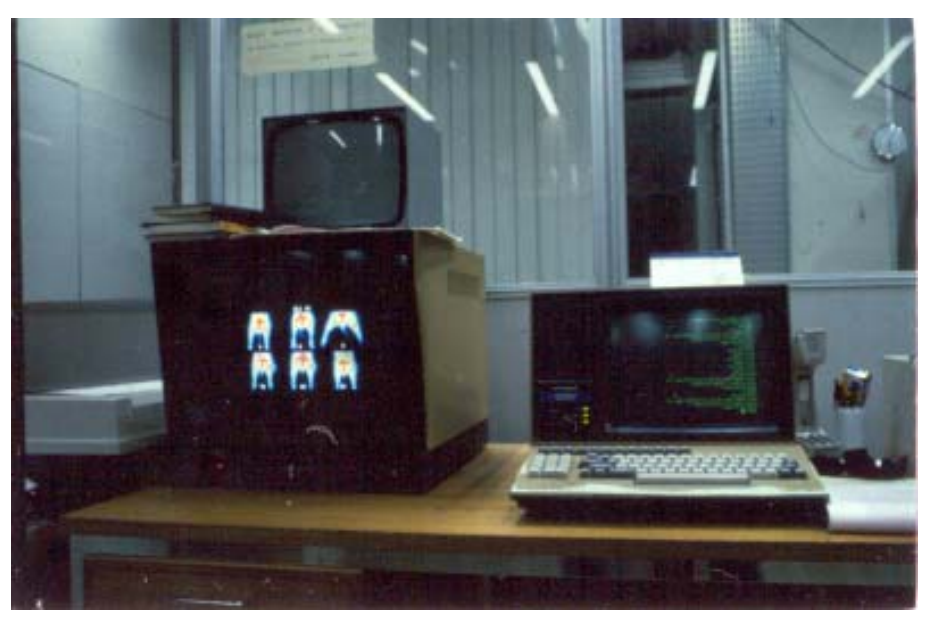

FIGURE 9 - SOPHA S-500 computer system.

The sequence for obtaining scintillographic images follows the previously described plan. 
Firstly, animals were immobilized on fixative ditches (FIGURE 10), specially created for this model. Images were taken 60 seconds after a venous injection of $18.5 \mathrm{MBq}(0.5 \mathrm{mCi}){ }^{\text {of }}{ }^{99 \mathrm{~m}} \mathrm{Tc}-$ pertechnetate in the marginal ear vein, the needed time in order that the radio drug was homogeneously spread within the vascular room. 300.000 images counting were accumulated, in the anterior projection of hips and thighs, involving the expanded region and the opposite side.

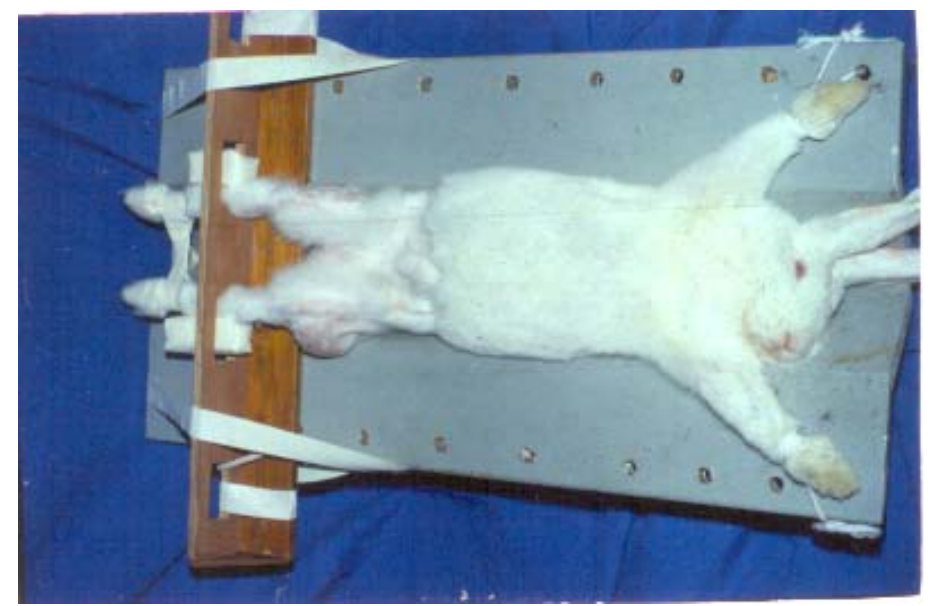

FIGURE 10 - Fixative ditches used for immobilizing the rabbit.

Images were stored in a computer and previously selected software was used. Quantitative analysis - Calculation of the Reperfusion Rate

Through a manual focuser, interest areas around the expanded cutaneous region, the 'expanded area', was highlighted and this same measure was transferred to the opposite side, the 'control area'. The blood volume of the region to be investigated was projected on the bounded area of the image (FIGURE 11).

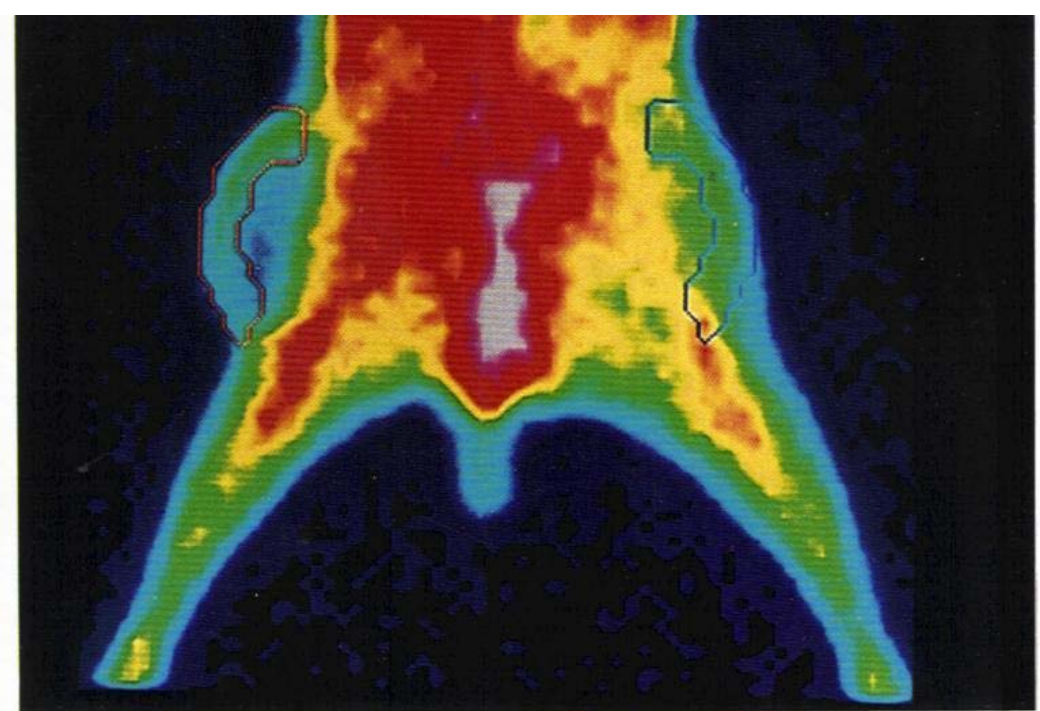

FIGURE 11 - Interest areas highlighted on the 'expanded area' (side R) and on the 'control area' (side L), for the calculation of the Perfusion Rate.

These interest areas provided the total number of counting, as well as the quantity of video matrix units.

The perfusion rate was defined (i) by the ratio:

$\mathrm{i}=\mathrm{C} / \mathrm{A}$, where

$\mathrm{i}=$ reperfusion rate

$\mathrm{C}=$ total number of counting and

$\mathrm{A}=$ area or video matrix units 
The Relative Perfusion Rate (I) calculation through the ratio between expanded area perfusion rate and control area rate. The computer was programmed to give directly the relative perfusion rate.

\section{Perspectives}

This experimental model may be used for future researches related to the skin blood circulation, by using a number of procedures that may be applied by the Medicine, especially by the Plastic Surgery.

\section{Acknowledgement}

We would like to thank Ludmila Aimi Kobayashi for the inestimable collaboration with carrying this study out.

\section{References}

1. Radovan C - Reconstruction of the breast after radical mastectomy using temporary expander. Plast Surg Forum. 1978;1:41.

2. Austad ED, Pasyk KA, McClatchey KD, Cherry GW - Histomorphologic evaluation of guinea pig skin and soft tissue after controlled tissue expansion. Plast Reconstr Surg. 1982;70:704-10.

3. Bartell TH, Mustoe TA - Animal models of human tissue expansion. Plast Reconstr Surg. 1989; 83:681-6.

4. Lindner P, Wolf F, Schad N - Assessment of regional blood flow by intravenous injection of 99mtechnetium-pertechnetate. Eur J Nucl Med. 1980;5:229-35.

5. Powell MR, Anger HO - Blood flow visualization with the scintillation camera. J Nucl Med. 1966;7:729-32.

6. Saxby PJ - Survival of island flaps after tissue expansion: a pig model. Plast Reconst Surg. 1988;81:304.

7.Stark GB, Hong C, Furtrell JW - Rapid elongation of arteries and veins in rats with a tissue expander. Plast Reconst Surg. 1987;80:570-8

8.Timmenga EJF, Schoorl R, Bos JD, Klopper PJ - An improved model for tissue expansion and flap research in the rabbit. Br J Plast Surg. 1989;42:301-5.

Horibe EK, Horibe K. Avaliação da perfusão radio-isotópica das mudanças da circulação sanguínea na pele submetida à expansão progressiva - modelo experimental em coelhos. Acta Cir Bras [serial online] 2004 Vol 19 Edição Especial. Disponível em URL: http://www.scielo.br/acb.

RESUMO - Este modelo experimental em coelhos tem como proposição investigar a variação do fluxo sanguíneo na pele expandida em relação ao tempo de expansão. Utilizam-se coelhos da raça Nova Zelândia. Estudam-se dois grupos : F-1 que recebe expansor na coxa direita e F-2 que recebe expansores bilateralmente. São feitas progressivamente cinco expansões. Realiza-se a primeira avaliação perfusional radioisotópica logo após o ato operatório e as seguintes no segundo, sexto, décimo-terceiro, vigésimo e vigésimo-sétimo dia pós-operatórios. Utiliza-se como radiotraçador o tecnécio $99 \mathrm{~m}$ na forma química de pertecnetato de sódio. Obtêm-se as imagens cintilográficas em câmara de cintilação CGR. Faz-se a análise quantitativa pelo cálculo do Índice de reperfusão.

DESCRITORES - Perfusão. Radioisotópos. Expansão de Tecido. Pele. Modelo Animal. Coelho.

Correspondence:

Edith Kawano Horibe

R. Afonso Brás, 525 / cjs 61-53

04511-011 São Paulo - SP

Tel: (11) 38420744

ckehoribe@uol.com.br 